\title{
PROBLEMS OF ONLINE LEARNING DURING COVID-19 PANDEMIC IN SPEAKING FOR PROFESSIONAL CONTEXT CLASS
}

\author{
${ }^{\# 1}$ Sri Ariani, ${ }^{* 2}$ Tawali \\ ${ }^{\# 1}$ English Lecturer, Faculty of Culture, Management and Business (FBMB), UNDIKMA, \\ Indonesia \\ ${ }^{* 2}$ English Lecturer, Faculty of Culture, Management and Business (FBMB), UNDIKMA, \\ Indonesia
}

Corresponding Author Email: $\underline{\text { sri_ariani@ikipmataram.ac.id }}$

\begin{abstract}
A B S T R A C T S
Indonesia's Government has made policy in the education sector due to the COVID-19 pandemic situation. Previously teaching and learning process especially in the higher institution is held face to face, and it switches to fully online learning. This situation forces the lecturer and students to adopt online learning and effected to their learning experiences. This current study is aimed at analyzing the students' difficulties during online learning in speaking for professional context subject during COVID-19 situation. This research was held using a descriptive qualitative method approach. The data was obtained from an online questionnaire and interview conducted to 45 students of the second semester of the English Department who joining speaking for professional context class at Universitas Pendidikan Mandalika in Mataram, West Nusa Tenggara, Indonesia. The findings of the research revealed various problems for students as indicated in the current research. A total of 5 problems arose during online learning in the Speaking for Professional class. The arisen problem was: The first problem was related to Youtube video as the source of learning materials. The second problem was dealing with the students' difficulties in elaborating the materials given by the lecturer during an online class. The third problem was related to the students' procedure in doing the project or assignment given by the lecturer. The fourth problem was dealing with Students' limitations in accessing ZOOM Meetings. The Students' learning equipment and supporting facilities also contributed as the fifth arisen problems of the students while having online learning during COVID-19 pandemic situations. The findings provide information for further development and improvement in online teaching and learning procedures. Further research on the strategy of how the students face the challenge and adapt are encouraged.
\end{abstract}

\begin{tabular}{l}
\hline \multicolumn{1}{c}{ A R T I C L E I N F O } \\
\hline Article History: \\
Received: May, 2021
\end{tabular}

Revised: May, 2021

Published: June, 2021

\begin{tabular}{l}
\hline Keywords: \\
Online Learning, \\
COVID-19 pandemic, \\
Speaking for Professional \\
Context Class,
\end{tabular}

Keywords:

Online Learning,

Speaking for Professional

Context Class,

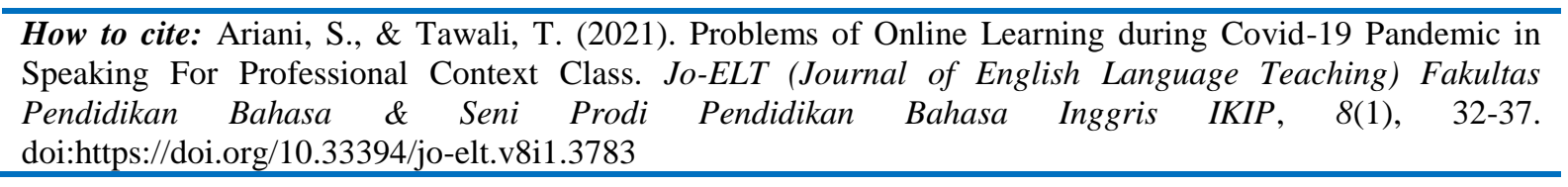

\section{INTRODUCTION}

In early 2020, several countries in the world, including Indonesia, were facing problems that changed activities of life caused by a virus called Covid-19. The influence of the Coronavirus disease 2019 (COVID-19) pandemic is now beginning to merge with the education sector. Therefore the government issued the policy for all educational institutions 
to prevent the spread of the COVID-19 by reducing the interaction of many people. Particularly in Universitas Pendidikan Mandalika in Mataram, West Nusa Tenggara, the relevant authorities imposed this policy early on April 20, 2020. The teaching and learning model switched from mostly face-to-face learning to online learning. As a result, it gives a different experience to everyone involved, especially to the students as remote learning, and many lecturers had less previous experience in online teaching.

Some researchers have been conducted research related to online learning in COVID19, Ali (2020) explored online and remote learning in higher institutions that investigate how EFL teachers implemented EFL online learning and the challenges they faced. While Allo (2020) conducted previous research which closes resemblance with the present study in which they both are concerned with the student's point of view of online learning in the pandemic situation. It was found that learner perception on online learning during COVID-19 pandemic.

Face-to-face learning lecturer and student are physically facing each other in being. Online learning, in contrast, involves teaching via online (this is related to the computer system or accessible by computer) connection between lecturer and the individual learner. That may present in the form of pictures, photos, or text documents exchanged electronically via the internet. Communication is completely different in an online class as compared to face-to-face. Anna (2020), an implementation consultant, stated that online learning is a great alternative. Online learning is a part of distance education that specifically combines electronic technology and internet-based technology or ICT in learning. Online learning is a program for organizing online learning classes to reach a broad and massive group of students. Online learning refers to the use of internet-based technology features, which are highly dependent on the availability of information technology.

Online learning is a learning system without directly face to face between teachers and students. Allen \& Seaman (2007) suggested the online learning requires an internet network. The teacher and students carry out learning together, at the same time, but in different places. Various applications and platforms can be used, such as Whatsapp, telegram, zoom meeting, google meet, google classroom, Edmodo, and others. To support this online learning, the main device needed is a computer or android connected to the internet network.

The effective way to transfer knowledge by the lecturer to the students in the face-toface classroom to online learning causing some problems, this was revealed by Anderson, Imdieke, and Standerford (2011). They stated that they saw one of the main challenges as the "disconnect between the way lecturers were taught to teach", and how the course content must be delivered in an effective online teaching environment. Teaching online distribution systems creates several difficulties and problems. A study conducted by Ahmad (2016) found a phenomenon that EFL learning which requires a lot of practice for its application also experiences obstacles when the learning system is used. In the listening session, for instance, the ICT equipment applied by teachers to train students who are in separate and distant places is often ineffective. Lecturers also cannot maximally supervise students when giving speaking exams. In speaking courses with distance or online learning, students also find problems in imitating the way of speaking exemplified by their lecturer, and the lecturer also cannot optimally train the students to speak.

The parents' abilities differ in providing their children supporting facilities. Because in this COVID-19 situation, most of the parents' lose their job. Some of them got salary reductions to support the continuation of the institution or company in which they work for. Another problem related to online learning is found that some students' parents and students do not have computer or android device, as such condition makes them hard to enjoy the learning system. Meanwhile, there is a demand for the fulfillment of educational services for students, as mandated in the constitution. 
In conducting an e-learning system, it is highly relevant with the notion of internet and technology as the support system. Especially in this 4.0 era, the lecturer has to master the internet and technology in teaching. Traditional face-to-face meetings are to be integrated with the blended-learning system by using e-learning. Lecturers are required to adapt to this latest information in the teaching and learning system. Particularly in facing this COVID-19 outbreak, the e-learning system is applied to accommodate the teaching and learning process from home, because this pandemic forces study from the home system.

In conducting the e-learning, some information and technology products can be employed in supporting the online classroom. The first supported application to accommodate e-learning is Whatsapp. Whatsapp is effective in increasing success in learning, developing students' positive opinions toward the use of Whatsapp in courses (Cetinkaya, 2017). Whatsapp is also an applicable tool for improving students' motivation to learn (Amry, 2016; Mbukusa, 2018). It is one of the most popular applications in nowadays communication. It is an unpaid mostly used chatting application.

There are many other free applications designed to assist the students and lecturer communicate and conduct online classrooms. The application applied such as Google Classroom, ZOOM, Google Meet, Facebook, Youtube, and so on. The lecturers may have an agreement with the students to choose the appropriate application in conducting the remote learning. It should be adjusted based on the lecturer's ability in accessing technology and students' condition, so the teaching and learning process can be managed effectively and efficiently.

\section{RESEARCH METHOD}

This research was conducted using a descriptive qualitative method approach. The data was obtained from the online questionnaire and interview result which was conducted on 45 students of the second semester of the English Department who joining speaking for professional context class at Universitas Pendidikan Mandalika in Mataram, West Nusa Tenggara, Indonesia. The questionnaire consisted of 20 questions. Four scale system was employed such as: strongly agree, agree, disagree, and strongly disagree. It was expected to give more honest responses as they were asked to reflect on their learning difficulties during the pandemic.

\section{Research Design}

In conducting this study, a qualitative study is applied to explores EFL students' experiences online during the COVID-19 pandemic in April 2021. The subject involved were EFL students who took Speaking in Professional Context subject at the time the policy of learning online was announced by Universitas Pendidikan Mandalika in Mataram, West Nusa Tenggara. The subject was taken purposively for the sake of easiness of access and because the subject they were taking is about online learning difficulties faced by EFL students during the COVID-19 pandemic.

\section{Population and Sample}

The subject of the study was 45 students who took the Speaking in Professional Context subject in the second semester of the English Department of Universitas Pendidikan Mandalika.

\section{Instruments}

The researcher conducted an online questionnaire and interview to collect valid information from the students dealing with their problems during having remote teaching and learning process. In this research, the researcher employed a semi-structured interview. The researcher had a list of questions for the subject but still be able to ask other questions which 
were not provided in the list. The main data were collected from students' speaking assignments reflected on their learning during the COVID-19 pandemic. An interview has the advantage of supplying large volumes of in-depth data rather quickly. Interviews are used to obtain data from people about opinions, beliefs, and feelings about situations in their own words. Interviews provide insight into participants' perspectives, the meaning of events for the people involved, information about the site, and perhaps information on unanticipated issues. Interviews allow immediate follow-up and clarification of participants' responses.

\section{Data Analysis}

In analyzing the data, the data were analyzed by describing the data collected based on an online questionnaire and interview result. The researchers referred to Miles and Huberman (1994). As activities in qualitative data analysis were carried out interactively and continuously to completion which was described in four steps. The four steps are data collection, data reduction, data display, and verification or conclusion.

\section{RESEARCH FINDINGS AND DISCUSSION \\ Research Findings}

Online learning is a learning system that uses an interactive model internet-based. Online learning is a program of organizing online learning classes to reach massive groups and wide targets. Online learning has become an inevitable choice for educational institutions. Lecturers can still teach, and students can still study in their own homes, during this COVID-19 pandemic. However, online learning is highly dependent on the availability of information and communication technology. WhatsApp was utilized in supporting online class learning. Cetinkaya (2017) said Whatsapp is effective in increasing success in learning, developing students' positive opinions toward the use of Whatsapp in courses. It is a free application and needs less internet quota. ZOOM Meetings was also utilized as a video conference to give a more clear understanding of the materials given during online class and to enable the students to double-check and follow up the lecturer's instruction.

Table 1

The Students Problems While Having Online Learning During COVID-19 Pandemic Situations

\begin{tabular}{|c|l|c|c|c|c|}
\hline \multirow{2}{*}{ No } & \multicolumn{1}{|c|}{ Problems } & \multicolumn{4}{|c|}{ Percentage (\%) } \\
\cline { 3 - 6 } & $\begin{array}{c}\text { Strongly } \\
\text { agree }\end{array}$ & Agree & Disagree & $\begin{array}{c}\text { Strongly } \\
\text { Disagree }\end{array}$ \\
\hline 1 & $\begin{array}{l}\text { Youtube video as } \\
\text { the sorce of } \\
\text { learning materials }\end{array}$ & 16.1 & 60.7 & 19.6 & 3.6 \\
\hline 2 & $\begin{array}{l}\text { The difficulties in } \\
\text { elaborating the } \\
\text { materials }\end{array}$ & 39.3 & 37.4 & 14.9 & 8.4 \\
\hline 3 & $\begin{array}{l}\text { Students' } \\
\text { procedure in doing } \\
\text { the project or } \\
\text { assignment given } \\
\text { by the lecturer }\end{array}$ & 41.1 & 48.2 & 10.7 & 0 \\
\hline 4 & $\begin{array}{l}\text { Students' limitation } \\
\text { in accessing } \\
\text { ZOOM Meeting }\end{array}$ & 17.9 & 57.1 & 21.4 & 3.6 \\
\hline 5 & $\begin{array}{l}\text { Students' learning } \\
\text { equipment and } \\
\text { supporting facilities }\end{array}$ & 19.6 & 66.1 & 14.3 & 0 \\
\hline & \multicolumn{1}{|}{ Avarage } & 26.8 & 54.08 & 16.18 & 3.12 \\
\hline
\end{tabular}




\section{Discussion}

Focussing on the students' problems during online learning, the data above only showed the revealed problems. The other aspect of the finding was described in the following discussion.

The first problem was related to Youtube videos as the source of learning materials. The findings showed that $16.1 \%$ and $60.7 \%$ strongly agreed and agree, meaning that $76.8 \%$ of the students had no problem when the lecture applied Youtube video of the source of learning materials as it provides clear instruction and interesting information for the students. However, $19.6 \%$ and $3.6 \%$ of them, a total of $23.2 \%$ implied that the duration of the video materials sometimes too long. The interview indicated the students get bored accessing it. Content of speaking material delivered online did not understand by all students.

The second problem was dealing with the students' difficulties in elaborating the materials given by the lecturer during an online class. The findings revealed $39.3 \%$ and $37.4 \%$ strongly agreed and agree, meaning that $76.7 \%$ of the students had problems in elaboration materials chosen by the lecturer as it was too hard to understand by the students. The interview revealed that they needed to call the lecturer to confirm and did crosschecking about the materials directly. However, $14.9 \%$ and $8.4 \%$ of them, a total of $23.3 \%$ had no problem elaborating the materials given by the lecturer during an online class. Meaning that they had the good capability in understanding the materials.

The third problem was related to the students' procedure in doing the project or assignment given by the lecturer. It was found that $10.7 \%$ of the students disagree with to conduct procedure given by the lecturer in doing their project or assignment. The interview showed when students had face-to-face learning in the classroom, they were interested in had peer or group discussions. It turns out when in the pandemic situation, most of them only reflect one way of English Spoken performance by the student all alone. Then after the students practice and record it, the students submit it. The students had limited access to have direct interactive communication. They are less concerned about the importance of EFL speaking subjects and assignment submission. As a result, assignments that should have been submitted within one week period were often stretched to two weeks. Consequently, the lecturer late to record and give the score for the students' works.

The fourth problem was dealing with students' limitations in accessing ZOOM Meetings. The findings revealed there was a total of $75 \%$ of the students had difficulties logging in and joined the class meeting via ZOOM meeting. The interview revealed mostly this happened due to bad internet connection and whether matter. When it is raining heavily with thunder in their place, the students choose to not to the joint online class and lost their opportunity to participate in the online discussions, and unable to give respond to the materials given.

The students' learning equipment and supporting facilities also contributed as the fifth arisen problems of the students while having online learning during COVID-19 pandemic situations. A total of $85.7 \%$ of the respondents had a problem in providing learning equipment and supporting facilities such as computers, androids, and the availability of an internet network. The interview showed that not all the students' parents were able to provide wifi or internet access for their children. This caused the students less motivated in learning to speak online. Various subjects in English Department required the students to provide internet quota maximally. the students need to spend their internet quota not only to access this Speaking for Professional Contexts online class, but also other subjects such as Listening in Professional Contexts class, Expository Writing Class, Inferential Reading Class, and Communicative English Grammer class. The students have difficulties in dividing the internet quota. Consequently, they run out of internet quota and disable to practice their English speaking skill optimally on online learning. 


\section{CONCLUSION}

From the description, it is understandable that online learning is an alternative solution for the learning process, including for EFL students, in the COVID-19 pandemic condition. Although it raises several problems, for lecturers and students, all parties must be ready to implement it. Therefore, this research is carried out online learning difficulties faced by EFL students during the COVID-19 pandemic and solutions to solve them. The researchers hope that the result of this study can be used as information and reference for lecturers, students, institutions, parents, and the government, to make policies in carrying out online learning. line with Nadim Makarim's statement (Kemendikbud, 2020) that the principle of education policy during the COVID-19 pandemic is to prioritize the health and safety of students, educators, education personnel, families, and society in general, and to consider the growth and development of students and psychosocial conditions in an effort fulfillment of education services.

\section{REFERENCES}

Ahmad, S. Z. (2016). The Flipped Classroom Model to Develop Egyptian EFL Students' Listening Comprehension. English Language Teaching, 9(9), 166-178.

Ali, W. (2020). Online and remote learning in higher education institutes: a necessity in light of COVID19 pandemics. Higher Education, 10(3), 16-25. https://doi.org/10.5539/hes.v10n3p16.

Allen, I. E., \& Seaman, J. (2007). Online Nation: Five Years of Growth in Online Learning. Newburyport, MA.: ERIC.

Allo, M. D. G. (2020). Is the online learning good in the midst of covid-19 pandemic? The case of EFL learners. Jurnal Sinestesia, 10(1), 1-10.

Amry, A. B. (2016). The Impact of Whatsapp Mobile Social Learning on the Achievement and Attitudes of Female Students Compared with Face to Face Learning in the Classroom. European Scientific Journal, 10(22), 116-136.

Anderson, D., Imdieke, S., \& Standerford, N. S. (2011). Feedback please: Studying self in the online classroom. International Journal of Instruction, 4, 3-15.

Anna. (2020, July 17). Is online learning as good as face to face learning? The truth revealed. Easy LMS. https://www.easy-lms.com/knowledge-center/lmsknowledge-center/isonline-learning-as-good-asface-to-face-learning/item12527.

Cetinkaya, L. (2017). The Impact of Whatsapp Use on Success in Education Process. The International Review of Research in Open and Distributed Learning, 18(7). https://doi.org/10.19173/irrodl.v18i7.3279.

Kemendikbud. (2020, October 15). Mendikbud Dan Mendagri Gelar Rakor Dengan Kepala Daerah Bahas Pembelajaran di Masa Pandemi. https://www.kemdikbud.go.id/main/blog/2020/09/mendikbud-dan-mendagri-gelarrakor-dengan-kepala-daerah-bahas-pembelajaran-di-masa-pandemi.

Mbukusa, N. R. (2018). Perceptions of Students on the Use of Whatsapp in Teaching Method of English as Second Language in the University of Namibia. Journal of Curriculum and Teaching, 7(2), 112-119. https://doi.org/10.5430/jct.v7n2p112.

Miles, M. B., \& Hubberman, A. (1994). Qualitative Data Analysis: An expanded sourcebook (2nd. Ed). London: SAGE. 